\title{
PELAKSANAAN AKUISISI DI SEKTOR PERTAMBANGAN BATUBARA DALAM PELAKSANAAN EKSPANSI PERUSAHAAN GROUP
}

\author{
Hartana \\ Kandidat Doktor Fakultas Hukum Universitas Gadjah Mada Yogyakarta \\ Direktur Utama PT. Bumi Kencana Eka Sejahtera \\ Email : hartana_palm@yahoo.com
}

\begin{abstract}
ABSTRAK
Akuisisi adalah membeli atau mendapatkan sesuatu/obyek untuk ditambahkan pada sesuatu/obyek yang telah dimiliki sebelumnya. Hasil dari penulisan ini adalah belum adanya aturan lelang tentang permohonan IUP baru, sehingga perusahaan tidak bisa megajukan permohonan penambahan IUP, dan Sebagai strategi atau aksi korporasi pendukung dari usaha inti. Perusahaan yang bergerak dalam sektor pertambangan batubara tidak hanya melakukan akuisisi perusahaan pemegang IUP saja, tetapi juga melakukan akuisisi terhadap perusahan pemilik pelabuhan dan Pembangkit Listrik Tenaga Uap.
\end{abstract}

Kata kunci : akuisisi, batubara, perusahaan

\section{ABSTRACT}

Acquisition is to buy or get something / object to add to something / object that has been owned before. The result of this writing is the absence of auction rules on new IUP applications, so the company can not apply for the addition of IUP, and as a strategy or supporting corporation action from core business. Companies engaged in the coal mining sector not only acquire IUP holding companies but also acquire companies owned by ports and Steam Power Generators.

Keywords: acquisition, coal, company

\section{Pendahuluan}

Batubara merupakan bahan bakar fosil yang terbentuk dari sisa tumbuhan pada jaman pra-sejarah yang berubah bentuk. Pada awalnya sisa tumbuhan berakumulasi di rawa dan lahan gambut yang terkubur di kedalaman tertentu dan mengalami suhu dan tekanan tinggi yang menyebabkan tumbuhan tersebut mengalami proses perubahan fisika dan kimia.

Batubara yang terbentuk
mempunyai beberpa kelas (rank)
berdasarkan
pembentukannya. Kelas batubara
dilihat dari pembentukannya
berurutan dari mulai yang paling
muda, antara lain : lignite - sub
bituminous - bituminous -
antrachite. Sumberdaya batubara
adalah keseluruhan endapan
batubara yang terkandung di bawah


permukaan bumi, sedangkan cadangan batubara adalah bagian dari sumberdaya batubara yang jumlah dan keberadaannya telah diketahui dengan pasti serta dapat diproduksi ke atas permukaan bumi dengan teknologi yang ada saat ini. Sumberdaya dan cadangan batubara volumenya bersifat dinamis yang selalu berubah dengan adanya kegiatan eksplorasi dan poduksi.

Semua bahan bakar yang berasal dari fosil akhirnya akan habis. Oleh karena itu penting sekali untuk mengelola sumberdaya batubara secara efisien, sehingga memberikan manfaat yang sebesarbesarnya dalam jangka waktu yang lama. Pengelolaan yang baik dilakukan mulai tahapan eksplorasi sampai dengan pemanfaatan. Pada tahap eksplorasi adalah dengan meningkatkan penemuan cadangancadangan baru melalui kegiatan eksplorasi yang sudah berjalan. Pada tahap eksploitasi perlu dikembangkan pembaharuan dalam teknik-teknik penambangan, sehingga dapat memperoleh cadangan-cadangan yang sebelumnya tidak bisa dicapai. Sedangkan pada pemanfaatannya dilakukan pengembanganpengembangan penting mengenai penggunaan batu bara secara efisien sehingga dapat diperoleh energi yang lebih banyak dari setiap ton batu bara yang diproduksi.

Indonesia merupakan salah satu negara yang beruntung memiliki kekayaan sumber daya alam yang cukup"besar", baik sumber daya yang tidak dapat terbaharui maupun yang dapat terbaharui. Dalam konteks ini tidak digunakan kata "melimpah", sebab kata "besar" itu adalah relatif. Sementara, kata"melimpah"seolah tidak habis-habis atau tidak terbatas. Contohnya, sumber daya batubara Indonesia sebesar 104 miliar ton dan cadangan 21 miliar ton. Itu angka yang "besar," tapi dalam tingkat dunia masih relatif kecil. Berdasarkan data BP Statistical Review 2010, cadangan Indonesia hanya 0,5 persen dari cadangan dunia, sedangkan bila kita berasumsi 21 miliar ton dihitung semua sebagai cadangan yang mineable jumlahnya tidak sampai 2,5 persen. Potensi mineral dan batubara tersebar di berbagai kepulauan di Indonesia. Karena memiliki potensi ekonomi yang cukup besar maka sejak lama sumber daya mineral dan batubara telah menjadi andalan pembangunan ekonomi (Warta Minerba;2011;1).

Pengusahaan

batubara pertama kali dilakukan di Pengaron, Kalimantan Selatan, pada tahun 1849 oleh NV Oost Borneo Maatsnhappij "Benteng Emas". Selanjutnya Belanda juga mendirikan dua perusahaan tambang batubara lain di dekat Martapura, yaitu Julia Hermina dan Delft. Pada tahun 1888, penambangan batubara dibuka di Batu Panggal, Kutai, Kalimantan Timur oleh L.H. Menten. Menten juga membuka upaya eksploitasi minyak 
bumi pertama di wilayah Kutai. Kegiatan penyelidikan batubara terus dilanjutkan. Penyelidikan batubara pada 1915-1918 di Sumatera Selatan menghasilkan sumberdaya dan cadangan batubara baru. Pada tahun 1919, Belanda membuka penambangan batubara di Tanjung Enim dengan metode penambangan terbuka di tambang Air Laya. Pada tahun 1923-1940, penambangan dilakukan dengan metode penambangan bawah tanah. Pemenuhan kepentingan komersial dilakukan mulai tahun 1938 oeh penambangan batubara Bukit Asam, yaitu pada Air Laya untuk batubara jenis bituminous dan Suban untuk batubara jenis semi antrasit. Pada tahun 1950, Pemerintah Republik Indonesia mengesahkan pembentukan Perusahaan Negara Tambang Arang Bukit Asam (PN TABA) seiring berakhirnya kekuasaan pemerintah Kolonial Belanda (Irwandy, 2014;37).

Perusahaan-perusahaan yang bergerak di bidang pertambangan di Indonesia biasanya berbentuk group. Tercatat terdapat 30 group yang bergerak dalam industri pertambangan Indonesia, diantaranya adalah BUMI Plc group, ADARO group, BAYAN group, INDIKA group, BANPU group, BA group, BORN group, TANITO group, ASTRA group, SINAR MAS group dan masih banyak yang lainnya (Sulistiowati, 2011). Dominasi keberadaan perusahaan group dibandingkan perusahaan tunggal di Indonesia ditunjukkan oleh perusahaan- perusahaan berskala besar tidak lagi dijalankan melalui bentuk perusahaan tunggal, tetapi mengunakan konstruksi perusahaan group.

Adapun cara yang dapat digunakan untuk membentuk perusahaan group adalah dengan melakukan merger, akuisisi atau membentuk perusahaan baru. Perusahaan-perusahaan melakukan ekspansi melalui merger, akuisisi atau membentuk perusahaan baru dengan maksud dapat mengurangi perusahaan pesaing atau mengurangi persaingan. Selain itu, ekspansi melalui merger, akuisisi atau membentuk perusahaan baru akan mendorong perusahaan memiliki jenis usaha yang lebih besar tanpa harus melakukannya dari awal. Dalam artikel ini akan dibahas berkenaan dengan Pelaksanaan Akuisisi Di Sektor Pertambangan Batubara Dalam Pelaksanaan Ekspansi Perusahaan Group.

\section{Bentuk Perusahaan dan Status Hukumnya}

Bentuk perusahaan dapat dilihat dari status hukumnya, yaitu berbentuk tidak badan hukum atau berbentuk badan hukum. Status hukum suatu perusahaan badan hukum atau tidak badan hukum ini penting untuk diketahui karena menyangkut kedudukan, hak dan kewajiban serta tanggung jawab perusahaan tersebut, khususnya jika akan berhubungan dengan pihak ketiga. Dalam artian apakah suatu 
perusahaan itu dapat menjadi subyek hukum, dapat melakukan perbuatan hukum, sehingga mempunya hak dan kewajiban dan dapat dipertanggungjawabkan terpisah dari perseorangan. Inilah persoalan yang menyangkut status hukum dari suatu perusahaan (Murjianto R, 2002;1).

Mengenai pengertian badan hukum ini memang di dalam Undang-undang tidak ada batasan pengertiannya, namun secara umum dapat diberikan pengertiannya, bahwa badan hukum adalah segala sesuatu yang dapat mempunyai hak dan kewajiban dan dapat melakukan perbuatan hukum, dapat menjadi subyek hukum, dan dapat dipertanggungjawabkan. Badan hukum mempunyai hak dan kewajiban, harta kekayaan dan tanggung jawab yang terpisah dari orang perseorangan.

Adapun diantara macammacam bentuk perusahaan itu yang berstatus tidak badan hukum antara lain :

1. Persekutuan Perdata

2. Persekutuan Firma

3. Persekutuan Komanditer Sedangkan bentuk perusahaan yang berstatus badan hukum antara lain :

1. Perseroan Terbatas

2. Koperasi

3. Yayasan

4. Perusahaan Negara

\section{Pengertian Akuisisi}

Menurut pendapat Moin (2004:8), Berasal dari kata acquisitio
(Latin) dan acquisition (Inggris), makna harfiah akuisisi adalah membeli atau mendapatkan sesuatu/obyek untuk ditambahkan pada sesuatu/obyek yang telah dimiliki sebelumnya. Akuisisi dalam arti terminologi adalah pengambilalihan kepemilikan atau pengendalian atas saham atau aset suatu perusahaan oleh perusahaan lain, dan dalam peristiwa ini baik perusahaan pengambil alih atau yang diambil alih tetap eksis sebagai badan hukum yang terpisah. Peraturan Pemerintah Republik Indonesia No. 27 Tahun 1998 dalam (Moin, 2004:8) tentang Penggabungan, Peleburan, dan Pengambilalihan Perseroan Terbatas, Akuisisi adalah perbuatan hukum yang dilakukan oleh badan hukum atau orang perseorangan untuk mengambil alih baik seluruh atau sebagian besar saham perseroan yang dapat mengakibatkan beralihnya pengendalian terhadap perseroan tersebut.

Pendapat Widjaja (2002:50), Akuisisi oleh Encyclopedia of Banking and Finance didefinisikan sebagai a generic term for the taking over of one company by another, dan dalam Black's Law Dictionary diartikan sebagai the act of becoming the owner off certain property; the act by which one acquires or purchases the property in anything. Dalam pengertian hukum perusahaan secara umum dapat diterjemahkan sebagai pengambilalihan suatu perusahaan 
oleh perusahaan lainnya. Dari beberapa pengertian akuisisi diatas, dapat diambil kesimpulan bahwa akuisisi adalah tindak pengambilalihan kepemilikan suatu perusahaan oleh perusahaan lain yang mengakibatkan perusahaan yang diakuisisi dibawah kendali perusahaan pengakuisisi. Tetapi nama perusahaan masih tetap menggunakan nama perusahaan masing-masing.

Menurut (Agus Sartono, 2001), jika dilihat dari segi motivasi mengapa akuisisi dilakukan, maka akuisisi dapat dibeda-bedakan sebagai berikut: a. Akuisisi Strategis

Pada akuisisi strategis, latar belakang yang menyebabkan mengapa akuisisi dilakukan adalah untuk meningkatkan produktivitas perusahaan. Sebab, dengan akuisisi diharapkan dapat meningkatkan sinergi usaha, mengurangi risiko (karena diversifikasi), memperluas pangsa pasar, meningkatkan efisiensi, dan sebagainya

b. Akuisisi Finansial

Akuisisi Finansial adalah akuisisi yang dilakukan untuk mendapatkan keuntungan finansial semata-mata dalam waktu sesingkat-singkatnya. Akuisisi ini bersifat spekulatif, dengan keuntungan yang diharapkan lewat pembelian saham/aset yang murah, tetapi dengan income perusahaan target yang tinggi.

Sedangkan menurut Moin (2004:8) klasifikasi akuisisi berdasarkan obyek yang diakusisi dibedakan menjadi dua, yaitu:

a. Akusisi Saham

Istilah akuisisi digunakan untuk menggambarkan suatu transaksi jual beli perusahaan, dan transaksi tersebut mengakibatkan beralihnya kepemilikan perusahaan dari penjual kepada pembeli. Karena saham didirikan atas saham, maka akuisisi terjadi ketika pemilik saham menjual saham-saham mereka kepada pembeli / pengakuisisi. Pada peristiwa ini, pengakuisisi tidak harus meminta persetujuan dari pihak manajemen target, tetapi ada kalanya pembelian saham tersebut dilakukan dengan terlebih dahulu melakukan negosiasi dan penawaran dengan pihak manajemen atau dewan direksi perusahaan target. Jika manajemen perusahaan target setuju, maka mereka akan menginformasikannya kepada pemegang saham. Jika pemegang saham setuju atas tawaran yang diajukan oleh manajemen tersebut maka "deal" akan segera terwujud. Selanjutnya perusahaan diakusisi akan menjadi anak perusahaan pengakuisisi (Wahyu Hadi Kuncoro;2014).

b. Akusisi Aset

Apabila sebuah perusahaan bermaksud memiliki perusahaan lain maka ia dapat membeli sebagian atau seluruh aktiva atau aset perusahaan lain tersebut. Jika pembelian tersebut hanya sebagian dari aktiva perusahaan maka hal ini dinamakan akuisisi parsial. Akuisisi aset dilakukan apabila pihak 
pengakusisi tidak ingin terbebani hutang yang ditanggung oleh perusahaan target. Berbeda dengan akuisisi saham dimana kewajiban atau hutang target yang ada ditanggung oleh pemilik baru. Akusisi aset dimaksudkan untuk menghindari tanggung jawab ini. Namun demikian kalau proporsi aset yang dibeli melebihi batas tertentu sebagaimana diatur dalam peraturan pemerintah, maka pembeli harus ikut menanggung kewajiban hutang perusahaan target (.

Akuisisi dapat mengambil bentuk-bentuk sebagai berikut: Akuisisi horizontal, Suatu akuisisi yang dilakukan oleh suatu perusahaan terhadap kompetitornya ; Akuisisi vertical, Suatu akuisisi yang biasanya dilakukan terhadap pemasok, konsumen, langganan, atau distributor dan perusahaan yang mengakuisisi, Akuisisi interna, Suatu Akuisisi yang dilakukan antar perusahaan yang tergabung dalam satu grup; Akuisisi eksternal, Suatu akuisisi yang dilakukan oleh suatu perusahaan terhadap perusahaan lainnya yang bukan satu grup.

Dalam bentuknya tersebut akuisisi berbeda dengan merger, tidak mengenal

bentuk yang fungsional, seperti pada bentuk Pure Conglomerate Merger, kecuali yang dilakukan dalam bentuk akuisisi internal antar grup. Pada umumnya akuisisi dilakukan oleh suatu perusahaan terhadap perusahaan lain yang menunjang bidang usaha dan perusahaan yang mengakuisisi tersebut, baik yang dilakukan secara horisontal maupun vertikal.

Pada prinsipnya, suatu akuisisi dilakukan dengan dilatarbelakangi oleh salah satu atau lebih maksud sebagai berikut :

1. Akuisisi untuk Mengeksploitasi Energi

Salah satu alasan yang kerapkali dikemukakan oleh orang-orang dalam melakukan akuisisi adalah untuk menambah sinergi dari 2 (dua) perusahaan yang bergabung kepemilikan setelah akuisisi tersebut. Sinergi dari suatu akuisisi akan didapatkan antara lain dari terdapatnya faktor-faktor sebagai berikut: alih teknologi; pengetahuan pemasaran; pemotongan biaya; harmonisasi produk; penelitian dan pengembangan; penggunaan sumber daya yang optimum. Karena itu, sebelum dilakukan suatu akuisisi, haruslah terlebih dahulu diukur seberapa jauh sinergi tersebut akan dicapai dengan melakukan akuisisi yang bersangkutan. Jika ternyata sinerginya kurang dan alasan-alasan lain untuk akuisisi juga diragukan, biasanya perusahaan akan memilih membuka cabang yang baru ketimbang melakukan akuisisi usaha. Sebab, tidak semua akuisisi dapat menimbulkan sinergi.

2. Akuisisi untuk Meningkatkan Bagian Pasar. Akuisisi (dalam bentuk horisontal) dapat memperluas pasar dari produk yang dihasilkan, karena masingmasing perusahaan yang 
digabungkan dengan akuisisi tersebut mempunyai pasar sendiri-sendiri.

3. Akuisisi untuk Melindungi Pasar. Akuisisi akan melindungi pasar jika dengan akuisisi tersebut menyisihkan pesaing bisnis (jika perusahaan target adalah pesaing bisnis sendiri). Dari segi yuridis, yang harus diperhatikan adalah jangan sampai akuisisi seperti itu bertentangan dengan peraturan tentang larangan monopoli dan antitrust di negara yang bersangkutan.

4. Akuisisi untuk mengakusisi produk. Adakalanya perusahaan perlu mengembangkan usahanya untuk menghasilkan produk lain selain dari produk yang sudah ada. Untuk itu, dapat dilakukan akuisisi terhadap perusahaan lain yang sedang menghasilkan produk yang dikendakinya, dengan harapan produk tersebut nantinya setelah akuisisi akan dikembangkan lebih lanjut.

5. Akuisisi untuk Memperkuat Bisnis Inti. Adakalanya untuk memperkuat bisnis inti, suatu perusahaan perlu melakukan akuisisi perusahaan lain. Tentunya yang diakuisisi tersebut adalah perusahaan yang bergerak di bisnis inti tersebut. Dengan demikian, diharapkan bisnis inti dari perusahaan yang bersangkutan menjadi semakin besar dan kuat.

6. Akuisisi untuk Mendapatkan Dasar Berpijak Perusahaan di Luar Negeri Untuk sebuah perusahaan, terutama yang berambisi untuk cepat berkembang menjadi besar, seringkali diperlukan pengembangannya ke luar negeri. Untuk itu mengakuisisi perusahaan di luar negeri (crossboarder acquisition) adalah salah satu jalan yang dapat ditempuh.

7. Akuisisi untuk Meningkatkan Critical Mass-Competitive. Adakalanya suatu perusahaan dituntut untuk cepat menjadi besar untuk menjalankan bisnisnya. Misalnya, jika perusahaan tersebut ingin mengikuti tender-tender mega proyek. Agar dapat mencapai ukuran yang besar secara cepat, akuisisi perusahaan adalah jalan yang baik, termasuk akuisisi perusahaan diluar negeri.

Pembahasan

Pelaksanaan Akuisisi Di Sektor Pertambangan Batubara Dalam Pelaksanaan Ekspansi Perusahaan Group.

Yang dimaksud dengan akusisi/pengambilalihkan menurut ketentuan Pasal 1 butir 11 Undangundang Nomor 40 tahun 2007 tentang Perseroan Terbatas adalah perbuatan hukum yang dilakukan oleh badan hukum atau orang perseorangan untuk mengambil alih saham Perseroan yang mengakibatkan beralihnya pengendalian atas Perseroan tersebut. Menurut pasal 125 Undang-undang Nomor 40 tahun 2007 tentang Perseroan Terbatas, 
pengambilalihan dilakukan dengan cara pengambilalihan saham yang telah dikeluarkan dan/atau akan dikeluarkan oleh Perseroan melalui Direksi Perseroan atau langsung dari pemegang saham. Pengambilalihan dapat dilakukan oleh badan hukum orang perseorangan (Rahadiani, 2010).

Pengambilalihan sebagaimana dimaksud adalah pengambilalihan saham yang mengakibatkan beralihnya pengendalian terhadap Perseroan tersebut. Yang dimaksud dengan "pihak yang akan mengambil alih" dalam hali ini adalah Perseroan, badan hukum lain yang bukan Perseroan, atau orang perseorangan. Jadi, akusisi menutur hukum perseroan Indonesia adalah pengambilalihan yang mengakibatkan beralihnya kendali atas suatu badan usaha (Ireland, 2002).

Dalam hali ini pengambilalihan dilakukan oleh badan hukum terbentuk Perseroan, maka bagi Direksi berlaku ketentuan bahwa sebelum melakukan perbuatan hukum pengambialihan tersebut, Direksi harus mendapatkan keputusan RUPS yang membentuk kuorum kehadiran dan ketentuan tentang peryaratan pengambilan keputusan RUPS.

Ketentuan tentang persyaratan pengambilan keputusan RUPS tersebut diatur dengan jelas didalam ketentuan Pasal 89 Undang-undang Nomor 40 tahun 2007 tentang Perseroan Terbatas dan juga berlaku bagi pelaksanaan merger/penggabungan, yaitu sebagat berikut (Hadianto, 2001):

a. RUPS dapat dilangsungkan jika dalam rapat paling sedikit $3 / 4$ (tiga perempat) bagian dari jumlah seluruh saham dengan hak suara hadir atau diwakili dalam RUPS dan keputusan adalah sah jika disetujui paling $3 / 4$ (tiga perempat) bagian dari jumlah suara yanga dikeluarkan, kecuali anggaran dasar menentukan kuorum kehadiran dan/atau ketentuan tentang persyaratan pengambilan keputusan RUPS yang lebih besar.

b. Dalam hal kuorum kehadiran sebagaimana dimaksud pada butir (1) tidak tercapai, dapat diadakan RUPS kedua.

c. RUPS kedua sebagaimana dimaksud pada butir (2) sah dan berhak mengambil keputusan jika dalam rapat paling sedikit 2/3 (dua pertiga) bagian dari jumlah seluruh saham dengan hak suara hadir atau diwakili dalam RUPS dan keputusan adalah sah jika disetujui oleh paling sedikit $3 / 4$ (tiga perempat) bagian dari jumlah suara yang dikeluarkan, kecuali anggaran dasar jumlah suara yang dikeluarkan menentukan kuorum kehadiran dan/atau ketentuan tentang persyaratan pengambilan keputusan RUPS yang lebih besar (Chu, 2009).

Dalam hal kuorum RUPS kedua tidak tercapai maka Perseroan dapat memohon kepada ketua pengadilan 
negeri yang daerah hukumannya meliputi tempat kedudukan Perseroan atas permohonan Perseroan agar ditetapkan kuorum untuk RUPS ketiga. Pemanggilan RUPS ketiga harus menyebutkan bahwa RUPS kedua telah dilangsungkan dan tidak mencapai kuorum dan RUPS ketiga akan dilangsungkan dengan kuorum yang telah ditetapkan olehn ketua pengadilan negeri. Penetapan ketua pengadilan negeri mengenai kuorum RUPS sebagaimana dimaksud pada ayat (5) bersifat final dan mempunyai kekuatan hukum tetap.

Perlu ditetapkan bahwa Pemanggilan RUPS kedua dan ketiga dilakukan dalam jangka waktu paling lambat 7 (tujuh) hari sebelum RUPS kedua atau ketiga dilangsungkan. Ketentuan mengenai kuorum kehadiran dan/atau ketentuan tentang persyaratan pengambilan keputusan RUPS berlaku juga bagi Perseroan Terbuka sepanjang tidak diatur dalam peraturan perundangundangan dibidang pasar modal.

Dalam hal pengambilalihan dilakukan melalui Direksi, pihak yang akan mengambil alih menyampaikan maksudnya untuk melakukan pengambialihan kepada Direksi Perseroan yang akan diambil alih. Direksi Perseroan yang akan diambil alih dan Perseroan yang akan mengambil alih dengan persetujuan Dewan Komisaris masing-masing diwajibkan untuk menyusun rancangan pengambilalihan yang isinya memuat sekurang-kurangnya:

a. Nama dan tempat kedudukan dari Perseroan yang akan mengambil alih Perseroan yang akan diambil alih. (Muhammad, 2009).

b. Alasan serta penjelasan Direksi Perseroan yang akan mengambil alih dan Direksi Perseroan yang akan diambil alih.

c. Laporan keuangan untuk tahun buku terakhir dari Perseroan yng akan mengabil alih dan Perseroan yang akan diambil alih.

d. Tata cara penilaian dan konvi saham dari Perseroan yang akan diambil alih terhadap saham penukarannya apabila pembayaran pengambialihan dilakukan dengan saham.

e. Jumlah saham yang akan diambil alih.

f. Kesiapan pendanaan.

g. Neraca penyelesaian proforma Perseroan yang akan mengambil alih setelah pengambilalihan yang disusun sesuai dengan prinsip akuntansi yang berlaku umum di Indonesia.

h. Cara penyelesaian hak pemegang saham yang tidak setuju terhadap pengambialihan.

i. Cara penyelesaian satus, hak kewajiban anggota Direksi, Dewan komisaris, dan karyawan dari Perseroan yang akan diambil alih.

j. Perkiraan jangka waktu pelaksanaan pengambilalihan, 
termasuk jangka waktu pemberian kuasa pengalihan saham dari pemegang saham kepada Direksi Perseroan.

k. Rancangan perubahan anggaran dasar Perseroan hasil pengambilalihan apabila ada.

l. Pengambilalihan saham sebagaimana dimaksud diatas wajib pula memperhatikan ketentuan anggaran dasar Perseroan yang diambil alih tentang pemindahan hak atas saham dan perjanjian yang telah dibuat oleh Perseroan dengan pihak lain.

Khusus untuk pengambilalihan saham Perseroan lain yang dilakukan secara langsung dari pemegang saham, tidak perlu didahului dengan membuat rancangan pengambilalihan, tetapi dilakukan langsung melalui perundingan dan kesepakatan oleh pihak yang akan mengambil alih dengan pemegang saham dengan tetap memperhatikan anggaran dasar Perseroan yang di ambil alih. Berikut ini merupakan beberapa contoh akuisisi yang dilakukan oleh perusahaan group guna melaksanakan ekspansi di sektor pertambangan batubara.

\section{Akuisisi Yang Dilakukan Adaro Indonesia}

Untuk menciptakan nilai tambah yang berkelanjutan pada bisnis batubara, tahun 2011 lalu Adaro melalui anak usahanya PT. Alam Tri Abadi melakukan akuisisi $75 \%$ saham PT. Mustika Indah
Permai (MIP) dari Elite Rich Investment Limited senilai US\$222,5 juta atau setara Ro 1,89 triliun. MIP adalah perusahaan tambang batubara yang tengah mengembangkan proyek batubara baru (Greenfield) di Sumatera Selatan. Luas tambang yang dimiliki sekitar 2.000 ha dan telah memiliki IUP selama 20 Tahun sejak April 2010 lalu. Langkah akuisisi ini adalah strategi Adaro untuk mencapai kapasitas produksi sebanyak 80 juta ton pertahun. Jauh sebelum akuisisi dilakukan, Adaro telah melakukan penjajakan terhadap tambang ini dengan menggandeng MARTSON, perusahaan konsultan pertambangan internasional untuk melakukan studi rekayasa soal potensi batubara di tambang MIP (Pivi Princifal Yosefa Tarigan\&Wahyu Ario Pratomo;2014) .

Sebagai bagian dari strategi Adaro untuk membuka potensi cadangan batubara di Sumatera Selatan, di tahun yang sama Adaro melalui PT. Alam Tri Abadi juga telah mengakuisisi saham PT. Bukit Enim Energi (BEE) yang memiliki area tambang batubara seluas 11.130 ha dengan telah memagang IUP selama 20 tahun berlaku sejak Maret 2011 (Djajanti, 2013).

Adaro mengakuisisi saham BEE sebsar 46\% senilai US\$ 46 juta dari Lucky Star Corporation, Oriental Holdings dan Bright Path Corporation. Dengan akuisisi ini Adaro menguasai mayoritas $61 \%$ 
saham BEE, sisanya dimiliki oleh PT. Pamapersada Nusantara 20\%, PT. Triputra Utama Selaras $13.92 \%$ dari PT. Bumi Alam Sejahtera 5,04\% (Silvia. 2013).

Sebelumnya Adaro melalui PT. Alam Tri Abadi juga telah mengakuisisi 35\% saham PT. Servo Meda Sejahtera (SMS) dari PT. Servo Insfrastruktur senilai Rp 200 milyar. SMS adalah perusahaan penyedia jasa pertambangan batubara terintegrasi di Sumatera Selatan. SMS memiliki jalan khusus batubara di Sumatera Selatan yang memberikan layanan pengangkutan batubara, disamping itu, SMS juga memiliki pelabuhan khusus untuk pengangkutan batubara di pantai sebelah timur Sumatera Selatan yang memberikan layanan pemuatan batubara ke atas kapal. Setelah akuisisi, kompoisisi pemegang saham SMS berubah menjadi PT. Servo Insfrastruktur 50\%, PT. Tri Alam Abadi 35\% dan PT. Bumi Alam Sejahtera 15\%.

\section{Akuisisi Yang Dilakukan Group Indika}

Terhitung sejak tahun 2004, Indika Energy terus menambah konsesi tambang batubara. Dimulai dengan mengakuisisi 41\% kepemilikan saham Kideco. Kideco adalah perusahaan yang bergerak dalam pertambangan batubara tambang terbuka yang berlokasi di Kalimantan Timur. Kideco didirikan pada tahun 1982 dan merupakan PKP2B generasi pertama yang berlaku hingga tahun 2023. Pada tahun 2006, Indika Energy meningkatkan $5 \%$ penyertaannya di Kideco, sehingga menjadi $46 \%$ kepemilikan.

Tak berhenti disitu, tahun 2009 Indika kembali melakukan akuisisi 81,95\% saham PT. Petrosea Tbk (PTRO) senilai US\$ 83,8 juta. PT. Petrosea Tbk merupakan salah satu perusahaan terkemuka di bidang teknik dan konstruksi pengoperasian tambang dan logistik lepas pantai yang telah berpengalaman sejak 1972. Akuisisi ini merupakan bagian strategi Indika untuk melakukan diversifikasi investasi di sektor sumber daya energi, jasa konstruksi, dan infrastruktur di bidang energi.

Labih lanjut PT. Indika Energy Tbk melalui anak perusahaannya, PT. Indika Indonesia Resources dan Indika Capital Pte Ltd membeli 85\% saham dan hak pemasaran batubara di PT. Multi Tambangjaya Utama (MTU) pada tahun 2012 dari tangan International Coal Trading Limited. Nilai transaksinya sebesar US\$ 132 juta atau Rp 1,18 triliun. MTU merupakan produsen bituminous thermal coal dan coking coal berkualitas tinggi dengan PKP2B berbasis di Kalimantan Tengah, dengan wilayah konsesi seluas 24.970 hektar. Berlokasi di sekitar $30 \mathrm{~km}$ timur laut dari kota Ampah dan sekitar $250 \mathrm{~km}$ di utara Banjarmasin, MTU mengembangkan jalan angkut batubara berkapasitas 3,0 juta ton per tahun, sebuah conveyor jetty crusher berkapasitas 10,0 juta ton per tahun dan 
pelabuhan barges berkapasitas 5,0 juta ton per tahun dan terus meningkatkan dan memperluas infrastruktur guna mendukung operasi-operasi pertambangan masa depan.

MTU memiliki masa konsesi hingga tahun 2039. Akuisisi ini bertujuan untuk menambahkan aset batubara ke dalam portofolio sumber daya energi, serta melengkapi sumber daya batubara berkalori rendah yang telah dimiliki dengan yang berkalori tinggi dan coking coal, sehingga diharapkan dapat mengurangi dampak ketidakstabilan harga batubara global. Kehadiran MTU melengkapi daftar tambang batubara yang dikuasai Indika (Munandar, 2008).

Pada tahun yang sama Indika Energy memperoleh 60,0\% kepemilikan saham PT. Mitra Energi Agung (MEA), perusahaan merogoh kocek senilai US\$ 27 juta untuk mengambilalih saham MEA itu. Perseroan membeli saham tersebut dari Pacific Emperor Holdings Kimited. MEA adalah perusahaan pertambangan batubara yang memiliki IUP berlokasi di Kabupaten Kutai Timur, Kalimantan Timur. Perusahaan ini memiliki konsesi seluas 5.000 hektare dengan kualitas batubara sebesar 3.750

Adapun rincian dara perusahaan-perusahaan tersebut adalah sebagai berikut (Joseph M, 2000):

Kuansing Inti Makmur Block (KIM Block)

$\begin{array}{ll}\text { Perizinan } & : \text { IUP (2009-2029) } \\ \text { Luas } & : \text { 2.610 ha } \\ \text { Lokasi } & : \text { Kabupaten Bungo, Jambi }\end{array}$

hingga $4.000 \mathrm{kcal} / \mathrm{kg}$ atau termasuk batubara berkalori rendah. Selain itu, konsesi tersebut juga memiliki cadangan batubara sekitar 40 juta ton dan perkiraan sumberdaya batubara sekitar 100 juta ton.

\section{Akuisisi Yang Dilakukan Group Sinarmas}

Group Sinarmas juga tak ingin ketinggalan dalam melakukan akuisisi beberapa perusahaan tambang batubara. Tahun 2006 Perseroan mengakuisisi PKP2B yang terletak di Kalimantan Selatan, yakni PT. Borneo Indobara melalui Anak Perusahaan PT. Roundhill Capital Indonesia. Selanjutnya, Perseroan memperbesar kegiatan usaha utama di pertambangan dengan mengakuisisi beberapa wilayah penambangan baru yang terletak di Jambi dan Kalimantan Tengah. Terhitung antara tahun 2009 Operasi Propduksi PT. Kuansing Inti Makmur (KIM) dan anak perusahaan yang terletak di Kabupaten Bungo, Provinsi Jambi, serta IUP Operasi Produksi PT. Trisula Kencana Sakti (PT. TKS), yang berlokasi di Kabupaten Barito Utara dan Kabupaten Barito Timur, Provinsi Kalimantan Selatan. 2010, perusahaan beberapa IUP 
Anak Perusahaan :
a. PT. Karya Cemerlang Persada (143 ha)
b. PT. Tanjung Belit Bara Utama (198 ha)
c. PT. Bungo Bara Utama 1 (199 ha)
d. PT. Bungo Bara Utama 2 (199 ha)
e. PT. Berkat Nusantara Permai (199 ha)
f. PT. Bara Harmonis Batang Asam (172
ha)
g. PT. Tanjung Batang Asam (196 ha)

\author{
PT. Trisula Kencana Sakti (TKS) \\ Perijinan : IUP (2009-2028) \\ Luas : $11.455 \mathrm{ha}$ \\ Lokasi : Kabupaten Barito Utara dan Barito Timur, \\ Kalimantan Tengah
}

PT. Borneo Indobara (BIB)

Perijinan : PKP2B (2006-2036)

Luas : 24.100 ha

Lokasi : Kabupaten Tanah Bumbu, Kalimantan

Selatan

Tak berhenti disitu saja, tahun 2015

Group Sinarmas melalui anak usahanya Asia Coal Energy Ventures Limited (ACE) resmi menjadi pemegang saham pengendali PT. Berau Coal Energy Tbk (BRAU). Induk Berau, Asia Resources Minerals Plc (ARM), menerima tawaran Group Sinarmas ketimbang NR Holdings Limited milik Nathaniel Rothschild (Annisa CW, 2009).

ACE menyatakan telah menjadi pengendali di Berau Coal secara tidak langsung karena memiliki 94,19\% saham di ARM. Dengan demikian, ACE yang disokong dana oleh Group Sinarmas itu menguasai
84,7\% saham di Berau Coal melalui Vallar Investment UK Limited. ACE yang merupakan perusahaan terikat hukum Pulau Virgin, menyelesaikan akuisisi ARM pada 15 Juli 2015 pukul 13.00 waktu London. Pembayaran dilakukan pada waktu yang sama (Tampubolon, 2013).

\section{Simpulan}

Pelaksanaan ekspansi perusahaan group yang terjadi di sektor pertambangan. Setidaknya terdapat beberapa cara yang digunakan oleh perusahaan dalam melakukan ekspansi di sektor pertambangan batubara. Adapun 
cara yang dilakukan oleh perusahaan dalam melakukan ekspansi adalah akuisisi. Kegiatan akuisisi banyak dilakukan oleh sebuah perusahaan dalam ekspansi bisnisnya, hal ini dikarenakan oleh 2 (dua) hal, yaitu: Belum adanya aturan lelang tentang permohonan IUP baru, sehingga perusahaan tidak bisa megajukan permohonan penambahan IUP, dan Sebagai strategi atau aksi korporasi pendukung dari usaha inti. Perusahaan yang bergerak dalam sektor pertambangan batubara tidak hanya melakukan akuisisi perusahaan pemegang IUP saja, tetapi juga melakukan akuisisi terhadap perusahan pemilik pelabuhan dan Pembangkit Listrik Tenaga Uap.

\section{Daftar Pustaka}

Fakhruddin, M. dan M. Sopian Hadianto, 2001. Perangkat dan Model Analisis Investasi di Pasar Modal, PT Elex Media Komputindo Kelompok Gramedia, Jakarta.

Fuady, Munir, 1999. Hukum Tentang Merger, PT Citra Aditya Bakti, Bandung.

Hadi Kuncoro, Wahyu, 2014, Analisis Pengaruh Merger Dan Akuisisi Terhadap Kinerja Keuangan Perusahaan(Studi Kasus pada Perusahaan yang Terdaftar di Bursa Efek Indonesia Periode 20042013), Fakultas Ekonomika
Dan Bisnis Universitas Diponegoro Semarang. Hariyadi, Benny, et. al, WARTA MINERBA Majalah Direktorat Jenderal Mineral dan Batubara Kemana Pemanfaatan Sumber Daya Mineral dan Batubara Indonesia?, Direktorat Jenderal Mineral dan Batubara, Edisi XI Desember 2011.

Hitt, Michael A., Jeffrey S. Harrison dan R. Duane Ireland, 2002. Merger dan Akuisisi: Panduan Meraih Laba Bagi Para Pemegang Saham, PT Raja Frafindo Persada, Jakarta. Jogiyanto, 2003. Teori Portofolio dan Analisis Investasi, Edisi 3, BPFE-Yogyakarta, Yogyakarta.

Irwandy, Arif, 2014, Batubara Indonesia, PT. Gramedia Pustaka Utama, Jakarta.

Ma, Jianyu, José A. Pagán dan Yun Chu, 2009. "Abnormal Returns to Mergers and Acquisitions in Ten Asian Stock Markets", International Journal of Business, 14(3), USA.

Meta, Annisa CW, 2009. "Analisis Manajemen Laba dan Kinerja Keuangan Perusahaan Pengakuisisi Sebelum dan Sesudah Merger dan Akuisisi yang Terdaftar di Bursa Efek Indonesia Tahun 20082009". 
Moin, Abdul, 2004, Merger, Akuisisi dan Divertasi. Edisi 1, Ekonisia, Yogyakarta

Morris, Joseph M, 2000. Mergers and Acquisitions-Business Strategies for Accountants, John Wiley\&Sons, Inc, New York.

Murjianto R, 2002, Pengantar Hukum Dagang : AspekAspek Hukum Perusahaan dan Larangan Praktek Monopoli, Liberty, Yogyakarta.

Mustami, Adinda Ade dan Mimi Silvia. 2013. Akuisisi Marak di Sektor Energi, Ritel dan Bank.

Industri.kontan.co.id/news/ akuisisi-marak-di-sektorenergi-ritel-dan-bank Des. 2014).

Nababan, Tongam Sihol, Sere Eva Nababan dan Bantu Tampubolon, 2013. "Analysis of Relationship Between Market Reactions and Long Term Performance on Acquisitions", MPRA Paper, No. 49110.

Narimawati, Umi dan Dadang Munandar, 2008. Teknik Sampling: Teori dan Praktik dengan menggunakan SPSS 15, Gava Media, Yogyakarta. Nisfiannoor, Muhammad, 2009. Pendekatan Statistik Modern untuk Ilmu Sosial,Salemba Humanika, Jakarta.
Novaliza, Putri dan Atik Djajanti, 2013. "Analisis Pengaruh Merger dan Akuisisi terhadap Kinerja Perusahaan Publik di Indonesia (Periode 20042011)", Jurnal Akuntansi \& Bisnis, Vol. 1 September 2013.

Pivi Princifal Yosefa Tarigan dan Wahyu Ario Pratomo, Analisis Dampak Merger Dan Akuisisi Terhadap Abnormal Return Dan Kinerja Keuangan Pada Perusahaan Yang Terdaftar Di Bursa Efek Indonesia, Jurnal Ekonomi dan Keuangan Vol.3 No.3.

Sulistiowati, 2011, Limited Liability Dalam Limited Liability Pada Konstruksi Perusahaan Kelompok Piramida, Mimbar Hukum, Volume 23. Universitas Gadjah Mada.

Undang-undang Nomor 40 tahun 2007 tentang Perseroan Terbatas.

Widjaja, Gunawan, 2002. Merger dalam Perspektif Monopoli, PT RajaGrafindo Persada, Jakarta.

Wiriastari, $\quad$ Rahadiani, 2010. "Analisis Dampak Pengumuman Merger dan Akuisisi terhadap Return Saham Perusahaan Akuisitor yang Terdaftar di BEI Tahun 2004-2008”, Fakultas Ekonomi Universitas Diponegoro, Semarang. 